\title{
A Special Tribute to David A. Swinney, Ph.D.
}

\author{
Tracy Love
}

Published online: 29 March 2009

(C) The Author(s) 2009. This article is published with open access at Springerlink.com

Over the 13 years that I knew Dave, I knew him as: a mentor, professor, scientist, a resource for both graduate and undergraduate students, and as a friend.

As a mentor, Dave took a serious and active role in his students' graduate career. I witnessed the camaraderie that he shared with his students, which was often kept long after they embarked on their own careers.

As a professor, Dave was a knowledgeable, approachable and caring scholar who demanded that his students grasp broad reaching, multidisciplinary theory and motivations within the field.

As a scientist, Dave was revered. He was regularly invited to conferences all over the world, was the associate editor of JPR and was appointed to the Fachbeirat (International Scientific Council) for the Max-Planck Institute for Cognitive Neuroscience.

As a resource, Dave proved to be one of the most approachable and caring members of the Psychology Department at UCSD. As department chair, he was devoted to the bettering of graduate "life" and the curriculum.

Finally, I am honored to be able to say I knew Dave Swinney as a friend. After completing my doctoral studies, Dave and I worked for the next 8 years on collaborative research endeavors.

We had many a Sunday work days where we first had fun testing newly acquired gadgets - all with lots of good laughs mixed in throughout. In his last few years, he would often duck out of some of the weekend meetings to spend time walking on the La Jolla beaches with his wife Emmanuelle. She and Dave were so very happy and that happiness made all of us who were close to him smile.

Open Access This article is distributed under the terms of the Creative Commons Attribution Noncommercial License which permits any noncommercial use, distribution, and reproduction in any medium, provided the original author(s) and source are credited.

T. Love $(\bowtie)$

San Diego State University, San Diego, CA, USA

e-mail: tlove@mail.sdsu.edu 